\title{
Analisis Pengaruh Ketaatan Dan Kompensasi Terhadap Kinerja Pegawai Pada Kantor Sekretariat Daerah Kota Pontianak
}

\author{
HANAFI \\ MUNTAHA \\ STIE Boedi Oetomo \\ Jl. Ampera, No. GG 1-2 Kota Baru, Pontianak \\ email : stie_boedioetomo@yahoo.co.id
}

Diterima 4 September 2018; disetujui 15 November 2018;

\begin{abstract}
The purpose of this research is to examine the influence of obedience and compensation to performance at the office of the regional secretariat of Pontianak. The sample was 70 employees. The data was collected through questionnaire and analyzed with multiple linier regression. The result showed that obedience has a positive significant relationship to performance, while compensation didn't have relationship to performance at the office of the regional secretariat of Pontianak.
\end{abstract}

Keywords: Adherence, Compensation and Performance

\section{PENDAHULUAN}

Setiap instansi pemerintah dituntut untuk lebih profesional di dalam memberikan pelayanan kepada masyarakat sesuai dengan tugas dan fungsinya. Hal ini disebabkan karena semakin berkembangnya kehidupan masyarakat dibidang politik, ekonomi, social budaya dan keamanan dewasa ini. Selain itu instansi pemerintah memiliki keterbatasan kemampuan dana dan fasilitas untuk didayagunakan.

Kantor Sekretariat Daerah Kota Pontianak dalam mengemban tugas dan fungsinya memerlukan kemampuan manajemen untuk mendayagunakan segala sumberdaya yang dimiliki. Salah satu unsur manajemen atau sumber daya yang penting ialah Sumber Daya Manusia (SDM). Oleh karena itu dalam upaya meningkatkan kinerja organisasi diperlukan sumber daya manusia yang berkualitas dan professional untuk mengelola sumber daya manusia yang ada dalam organisasi itu. Sumber daya manusia dalam penulisan ini ialah keseluruhan
Pegawai Negeri Sipil (PNS) yang melaksanakan tugasnya pada Kantor Sekretariat Daerah Kota Pontianak.

Turun naiknya tingkat kinerja karyawan di Kantor Sekretariat Daerah Kota Pontianak ditandai dengan seringnya pekerjaan yang tidak dapat diselesaikan dengan tepat waktu atau tidak sesuai target yang telah ditentukan. Selain itu, kurang maksimalnya pekerjaan-pekerjaan yang dilakukan sehingga hasilnya tidak sesuai dengan apa yang diharapkan. Kondisi seperti ini apabila berlangsung terus menerus maka akan sangat merugikan, karena dapat mengakibatkan menurunnya tingkat kepercayaan dari masyarakat yang disebabkan rendahnya kinerja karyawan baik dari segi kualitas maupun kuantitas pekerjaan yang dilakukan. Sedangkan jika dilihat dari segi ketaatan karyawan adanya ketaatan dan kompensasi yang baik, maka kinerja akan semakin meningkat dan tidak mengalami penurunan. 
Sesuai dengan permasalahan yang akan diteliti maka tujuan dari penelitian ini adalah untuk mengetahui pengaruh ketaatan dan kompensasi terhadap kinerja pegawai pada Kantor Sekretariat Daerah Kota Pontianak.

\section{LANDASAN TEORI}

Ketaatan. Sinungan (2000) ketaatan sama dengan disiplin yang berarti kepatuhan terhadap ketentuan dan peraturan pemerintah atau etik, norma dan kaidah yang berlaku dalam masyarakat. Sastrohadiwiryo (2002) disiplin kerja dapat didefinisikan sebagai suatu sikap menghormati, menghargai, patuh dan taat terhadap peraturan-peraturan yang berlaku baik yang tertulis maupun yang tidak tertulis serta sanggup menjalankannya dan tidak mengelak untuk menerima sanksi-sanksinya apabila ia melanggar tugas dan wewenang yang diberikan kepadanya.

Menurut Hartanto dan Indra (2001), teori ketaatan menyatakan bahwa individu yang memiliki kekuasaan merupakan suatu sumber yang dapat mempengaruhi perilaku orang dengan perintah yang diberikannya. Hal ini disebabkan oleh keberadaan kekuasaan atau otoritas yang merupakan bentuk legitimate power atau kemampuan atasan untuk mempengaruhi bawahan karena adanya posisi khusus dalam struktur hierarki organisasi. Gaya otoriter yang berasal dari atasan juga membuat bawahan merasa jauh lebih diarahkan perilakunya kepada perilaku yang menyimpang dari konteks etika, khususnya etika profesi. Hal ini tergambar dalam paradigma mendasar mengenai ketaatan pada kekuasaan yang dikembangkan oleh Milgram (1974) yang dikatakan dalam pandangan paradigma teorinya bahwa bawahan yang mengalami tekanan ketaatan dari atasan akan mengalami perubahan psikologis dari seseorang yang berperilaku otonomis menjadi perilaku agendan membentuk sebuah dinamika keperilakuan yang dalam hal ini seorang bawahan merasa menjadi agen dari sumber kekuasaan, dan dirinya terlepas dari tanggung jawab atas apa yang dilakukannya. Hal ini terkait dengan personality seorang atasan yang memiliki otoritas terhadap arahan perusahaan. Sehingga mayoritas dari bawahan merasakan tekanan yang dilakukan oleh atasannya dapat dikategorikan sebagai suatu keharusan.

Kompensasi. Handoko (1998) kompensasi adalah sesuatu yang diterima pegawai sebagai balas jasa untuk kerja mereka. Tjahjono (1996), kompensasi tidak hanya sebatas upah atau gaji, tetapi mencakup segala sesuatu yang diberikan oleh Pemerintah sebagai balas jasa atas apa yang telah dilakukan oleh seorang pegawai. Dessler (1997), menyatakan bahwa kompensasi mencakup kompensasi finansial yang terdiri dari gaji dan tunjangan, juga kompensasi non finansial atau penghargaan yang dapat berupa kenaikan pangkat atau promosi jabatan.

Ruky (2002), menyatakan bahwa istilah kinerja atau prestasi kerja sebenarnya adalah pengalihbahasaan dari bahasa Inggris yaitu "performance". Suryadi Prawirosentono (1999) bahwa kinerja sebagai hasilatau output yang dicapai oleh seseorang dalam organisasi, dalam kerangka mencapai tujuan organisasi.

Bagi organisasi/perusahaan kompensasi berarti penghargaan kepada para pekerja yang telah memberikan kontribusi dalam mewujudkan tujuannya, melalui kegiatan yang disebut bekerja (Nawawi, 2003). Berdasarkan beberapa pengertian tersebut dapat disimpulkan bahwa definisi kepuasan kompensasi adalah sikap karyawan yang merasa senang atas besarnya jumlah imbalan, baik dalam bentuk finansial maupun non finansial sebagai balas jasa untuk kerja mereka.

Menurut Mondy dan Noe (2008), indikator kompensasi karyawan yaitu gaji adalah imbalan finansial yang dibayarkan kepada karyawan secara teratur, seperti tahunan, caturwulan, bulanan atau mingguan. Upah merupakan imbalan finansial langsung yang dibayarkan kepada para pekerja berdasarkan jam kerja, jumlah barang yang dihasilkan atau banyaknya pelayanan yang diberikan. Insentif merupakan imbalan langsung yang dibayarkan kepada karyawan karena kinerjanya melebihi standar yang ditentukan.

Penelitian Terdahulu. Rahmayanti (2014) analisis pengaruh kepemimpinan, motivasi, lingkungan kerja, dan kedisplinan terhadap kinerja karyawan PT. Astra Indonesia, hasil penelitian menunjukkan motivasi tidak berpengaruh positif terhadap kinerja karyawan variabel menunjukkan nilai t hitung sebesar 0,671 dengan taraf $p$ value 
0,504 .

Bartenputra (2016) dengan judul Pengaruh Kesesuaian Kompetensi, Ketaatan akuntansi dan Asimetri Informasi Terhadap Kecenderungan KecuranganAkuntansi. Hasil penelitian menunjukan bahwa kesesuaian kompetensi tidak berpengaruh terhadap kecenderungan akuntansi dan asimetri informasi berpengaruh signifikan positif terhadap kecendurungan kecurangan akuntansi.

Purnomo dan Dwiloka (2017), pengaruh motivasi kerja, kompensasi dan komunikasi pimpinan terhadap kinerja karyawan pada PT Bank Jateng Cabang Temanggung, hasil penelitian menunjukkan bahwa motivasi kerja, kompensasi dan komunikasi secara bersama-sama berpengaruh terhadap kinerja di PT Bank Jateng Cabang Temanggung.

\section{Hipotesis}

H1 : Terdapat pengaruh ketaatan terhadap kinerja Pegawai pada Kantor Sekretariat Daerah Kota Pontianak.

H2 : Terdapat pengaruh kompensasi terhadap kinerja Pegawai Pada Kantor Sekretariat Daerah Kota Pontianak

\section{METODE PENELITIAN}

Metode pendekatan yang dipakai dalam penelitian ini adalah metode penelitian survey dengan mengambil objek penelitian pada pegawai pada Kantor Sekretariat Daerah Kota Pontianak. Populasi dalam penelitian ini adalah semua pegawai pada Kantor Sekretariat Daerah Kota Pontianak sebanyak 703 orang dan sampel dalam penelitian ini sebesar $10 \%$ atau 70 orang yang dilakukan dengan cara acak berstrata (stratified random sampling). Variabel bebas (X) di dalam penelitian ini yaitu ketaatan dan kompensasi, sedangkan untuk variabel terikatnya $(\mathrm{Y})$ yaitu kinerja. Untuk mendapatkan data dalam penelitian ini menggunakan kuesioner, adapun yang mengisi kuesioner dalam penelitian ini adalah 70 orang pegawai pada Kantor Sekretariat Daerah Kota Pontianak yang juga sebagai sampel dalam penelitian ini.

Adapun definisi operasional di penelitian ini meliputi :

1. Variabel Bebas

a. Ketaatan (X1)

Sinungan (2000) ketaatan sama dengan disiplin yang berarti kepatuhan terhadap ketentuan dan peraturan pemerintah atau etik, norma dan kaidah yang berlaku dalam masyarakat.

b. Kompensasi(X2)

Handoko (1998) kompensasi adalah sesuatu yang diterima pegawai sebagai balas jasa untuk kerja mereka.

2. Variabel Terikat: Kinerja (Y)

Suryadi Prawirosentono (1999) bahwa kinerja sebagai hasil atau output yang dicapai oleh seseorang dalam organisasi, dalam kerangka mencapai tujuan organisasi.

Analisis data dipergunakan dalam penelitian ini adalah kualitatif dan kuantitatif terhadap data yang dikumpulkan dan diolah berdasarkan hasil dari pendapat responden berdasarkan kuesioner yang diberikan.

\section{HASIL DAN PEMBAHASAN}

Jumlah responden terbesar adalah responden yang berumur antara 41 - 50 sebanyak 41 orang $(58,57 \%)$ dan jumlah responden terkecil berada

\section{Gambar 1}

Kerangka Penelitian Analisis Pengaruh Ketaatan Dan Kompensasi Terhadap Kinerja Pegawai Pada Kantor Sekretariat Daerah Kota Pontianak

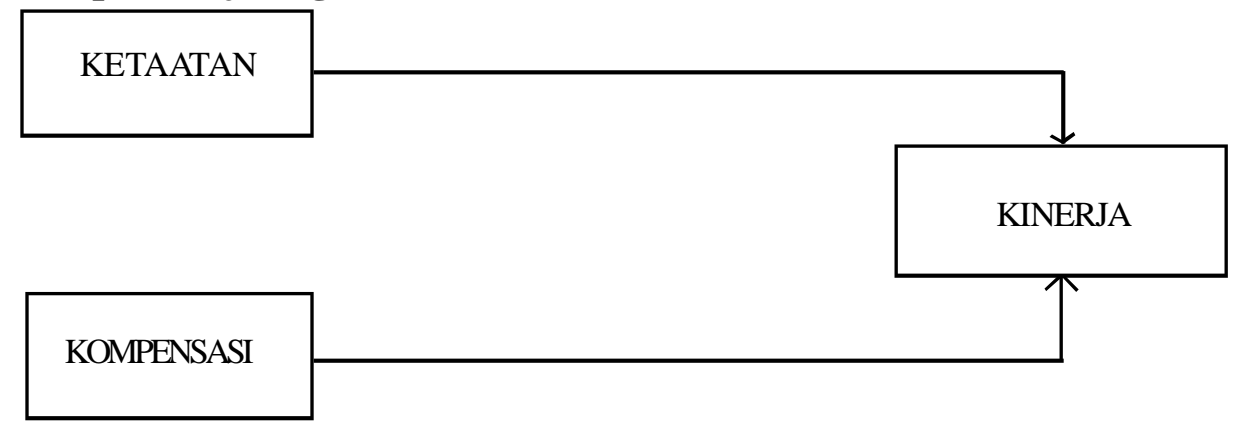


pada kelompok umur antara 51- 59 tahun sebanyak 4 orang atau $5,71 \%$. Jenis kelamin responden berdasarkan hasil pengamatan adalah sebanyak 44 orang responden $(62,86 \%)$ adalah laki-laki dan sebanyak 26 orang responden $(37,14 \%)$ perempuan. Jumlah respoden terbesar adalah berpendidikan SLTA sebanyak 45 orang $(64,29 \%)$, dan yang terkecil adalah berpendidikan S-2 sebanyak 4 orang $(5,71 \%)$.

\section{Tabel 1}

Dari hasil analisis data menunjukkan bahwa besarnya pengaruh dari variabel ketaatan kompensasi terhadap naik turunnya atau variasi variabel kinerja adalah sebesar 83,20\% sedangkan sebesar $16,80 \%$ dipengaruhi oleh variabel lain selain variabel dalam penelitian ini. Kesimpulan ini diperoleh dari nilai Koefisien Determinasi (R2) yaitu sebesar 0,832. Jadi dapat dikatakan bahwa variabel independent yang berupa ketaatan dan

Definisi Operasional Variabel

\begin{tabular}{clc}
\hline \multicolumn{1}{c}{ Variabel } & \multicolumn{1}{c}{ Defenisi } & Pengukuran \\
\hline $\begin{array}{l}\text { Variabel Bebas } \\
\begin{array}{l}1 . \text { Ketaatan } \\
\left(\mathrm{x}_{1}\right)\end{array}\end{array}$ & $\begin{array}{l}\text { Faktor ketaatan meliputi disiplin jam kerja dinas, batas } \\
\text { waktu dalam menyelesaikan tugas, serta ketaatan } \\
\text { untuk menyelesaikan tugas. }\end{array}$ & $\begin{array}{c}\text { Skala } \\
\text { 2.Kompensasi } \\
\left(\mathrm{x}_{2}\right)\end{array}$ \\
& $\begin{array}{l}\text { Faktor kompensasi yang Dimaksud adalah kompensasi } \\
\text { finansial Berupa gaji, Tunjangan dan insentif, sedangkan } \\
\text { kompensasi non finansial berupa penghargaan, kenaikan } \\
\text { pangkat dan promosi }\end{array}$ & Skala \\
& $\begin{array}{l}\text { Likert } \\
\text { Variabel Terikat: }\end{array}$ & \\
Kinerja $(Y)$ & $\begin{array}{l}\text { keterampilan yang dimiliki serta pengalaman baik dalam } \\
\text { bidang tugas maupun bidang lainnya. }\end{array}$ & Skala \\
\hline
\end{tabular}

Tabel 2

Analisis Of Variance Ketaatan Dan Kompensasi Terhadap Kinerja Pegawai Pada Kantor Sekretariat Daerah Kota Pontianak

\begin{tabular}{lrrrrr}
\hline \multicolumn{1}{c}{ Model } & Sum Of & Df & Mean & F & Sig. \\
& Square & & Square & & \\
\hline Regression & 24,171 & 2 & 12,086 & 165,689 & $.000^{\mathrm{a}}$ \\
Residual & 4,887 & 67 & 0,073 & & \\
\hline Total & 29,058 & 69 & & & \\
\hline
\end{tabular}

Sumber : Hasil Analisis Data, 2017

Tabel 3

Analisis Uji t, Ketaatan Dan Kompensasi Terhadap Kinerja Pegawai Pada Kantor Sekretariat Daerah Kota Pontianak

Coefficients

\begin{tabular}{|c|c|c|c|c|c|c|}
\hline & \multirow[t]{2}{*}{ Model } & \multicolumn{2}{|c|}{$\begin{array}{c}\text { Unstandardized } \\
\text { Coefficients }\end{array}$} & \multirow{2}{*}{$\begin{array}{c}\begin{array}{c}\text { Standardized } \\
\text { Coefficients }\end{array} \\
\text { Beta }\end{array}$} & \multirow[t]{2}{*}{$\mathrm{T}$} & \multirow[t]{2}{*}{ Sig. } \\
\hline & & $\mathrm{B}$ & Std. Error & & & \\
\hline \multirow[t]{3}{*}{1} & (Constant) & $-0,965$ & 0,216 & & $-4,470$ & 0,000 \\
\hline & KETAATAN & 1,193 & 0,110 & 0,825 & 10,875 & 0,000 \\
\hline & KOMPENSASI & 0,118 & 0,080 & 0,111 & 1,467 & 0,147 \\
\hline
\end{tabular}

Dependent Variable: KINERJA

Sumber : Hasil Analisis Data, 2017 
kompensasi pada penelitian ini berpengaruh terhadap kinerja pegawai Kantor Sekretariat Daerah Kota Pontianak.

Dari hasil analisis pada tabel 1 tersebut diketahui secara simultan nilai $\mathrm{F}$ hitung sebesar 165,689 pada tingkat signifikan 0.000a dan karena tingkat probabilitasnya 0.000 a jauh lebih kecil dari 0.05 maka model regresi ini dapat digunakan untuk memprediksi hubungan antara variabel independent terhadap variabel dependent. Nilai $F$ hitung $>$ nilai F tabel, yaitu 165,689 > 3,13, sehingga dapat disimpulkan bahwa antara variabel ketaatan dan kompensasi mempunyai pengaruh yang nyata terhadap kinerja pegawai pada Kantor Sekretariat Daerah Kota Pontianak.

Dari hasil analisis pada tabel 2 tersebut diketahui secara parsial variabel ketaatan memiliki nilai t hitung sebesar 10,875 dimana lebih besar dari $\mathrm{t}$ tabel $\alpha 0.05$, yaitu $10,875>1,667$. Maka dapat disimpulkan bahwa pada penelitian ini variabel ketaatan secara parsial mempunyai pengaruh yang nyata terhadap kinerja pegawai pada Kantor Sekretariat Daerah Kota Pontianak. Sedangkan variabel kompensasi memiliki nilai t hitung sebesar 1,467 dimana lebih kecil dari t tabel $\alpha 0.05$, yaitu $1,467<1,667$. Maka dapat disimpulkan bahwa pada penelitian ini variabel kompensasi secara parsial kurang mempunyai pengaruh yang nyata terhadap kinerja pegawai pada Kantor Sekretariat Daerah Kota Pontianak.

Variabel ketaatan dan kompensasi mempunyai pengaruh yang nyata terhadap kinerja pegawai pada Kantor Sekretariat Daerah Kota Pontianak. Hal ini didukung oleh keadaan bahwa para responden yang menyatakan pada kondisi sekarang kinerja pegawai yang ada cukup menunjang terciptanya loyalitas pegawai terhadap organisasi yang tentunya ditunjang oleh kompensasi yang memadai dan praktek manajemen yang lebih proporsional. Kondisi tersebut sesuai dengan tujuan utama setiap organisasi merancang sistem kompensasi adalah untuk memotivasi pegawai dalam rangka meningkatkan kinerjanya serta mempertahankan pegawai yang kompeten. Sistem imbalan ataupun sistem kompensasi yang baik tentunya akan memiliki dampak yang positif pada Kantor Sekretariat Daerah Kota Pontianak. Di satu sisi, selain akan mempengaruhi perilaku dan sikap kerja pegawai, kompensasi juga akan berdampak pada biaya operasi. Karenanya, organisasi harus benarbenar merancang sistem kompensasi secara efektif dan efisien. Hal ini dapat dipahami karena salah satu tujuan seseorang bekerja adalah mengharapkan imbalan dari organisasi dimana ia bekerja. Sedangkan, bagi pihak organisasi mengharapkan pegawainya memberikan kinerja yang terbaik bagi organisasi melalui ketaatannya.

\section{SIMPULAN}

\section{Kesimpulan}

1. Secara simultan dapat disimpulkan bahwa antara variabel ketaatan dan kompensasi mempunyai pengaruh yang nyata terhadap kinerja pegawai pada Kantor Sekretariat Daerah Kota Pontianak, bahwa nilai F hitung $>$ dari nilai tabel yaitu 165,689>3,13.

2. Secara parsial variabel ketaatan mempunyai pengaruh yang nyata terhadap kinerja, sedangkan kompensasi khususnya kompensasi non finansial kurang berpengaruh terhadap kinerja pegawai pada Kantor Sekretariat Daerah Kota Pontianak, karena berdasarkan hasil penelitian bahwa seluruh pejabat eselon memiliki kendaraan roda empat dan roda dua untuk menunjang tugas.

\section{Saran}

1. Ketaatan dan kinerja pegawai pada Kantor Sekretariat Daerah Kota Pontianak yang sudah cukup baik supaya tetap dipertahankan, bahkan ditingkatkan untuk memperoleh produktivitas yang lebih baik lagi.

2. Kompensasi non finansial dalam hal ini kebutuhan akan kendaraan roda empat dan roda dua untuk menunjang tugas para pejabat eselon supaya dipenuhi secara bertahap dalam rangka menunjang pelaksanaan tugas pada Kantor Sekretariat Daerah Kota Pontianak.

\section{DAFTAR PUSTAKA}

Dessler, Gary. Manajemen Sumber daya Manusia. JIli I Dan II. Edisi Bahasa Indonesia. PT. Prenhallindo. Jakarta. 1997.

Handoko, Tani. Manajemen Personalia dan Sumber Daya Manusia. Eidis Kedua, cetakan Kedua, 
BPFE, Yogyakarta. 1998.

Manullang. Manajemen Personalia. Gajam Mada University Press. Yogyakarta. 2001.

Prijono T dan Sutyatie. Pemberdayaan Penduduk dan Peningkatan Kualitas Sumber Daya Manusia. PT. Citra Putra Bangsa. Jakarta. 1998.

Ruky AS. Sistem Manajemen Kinerja (Performance Manajemen System). Cetakan Kedua. PT. Gramedia Pustaka Utama. Jakarta. 2002.

Satrohadiwiryo. B. Siswanto. Manajemen Tenaga Kerja Indonesia Pendekatan Adminsitratif dan Operasional. Bumi Aksara. Jakarta. 2002.
Saydam, Gouzali. Manajemen Sumber Daya Manusia. Jlid I. Toko Gunugn Agung. Jakarta. 1995.

Sinungan. M. Produktivitas Apa dan Bagaimana. Cetakan Keempat. Bumi Aksara. Jakarta. 2000.

Supranto. J. Ekonometrika. Penerbit BPFE. Universitas Indonesia.Jakarta. 2001.

Tjahjono. A. Kompemsasi Intensif Sebagai Alat Untuk Memotivasi Aggota Organisasi Dalan Upaya Mencapai Tujuan Organisasi. Kajian Bisnis. Nomor 8.1996. 